\title{
Sowing Time of Sweet Corn in Summer Season in Northwestern Paraná, Brazil
}

\author{
Antônio A. N. Franco ${ }^{1}$, Pedro S. Vidigal Filho ${ }^{2}$, Carlos A. Scapim ${ }^{2}$, Ricardo S. Okumura ${ }^{3}$, \\ Alberto Y. Numoto ${ }^{2} \&$ Odair J. Marques ${ }^{4}$ \\ ${ }^{1}$ Federal Institute of Pará, Paragominas City, Brazil \\ ${ }^{2}$ State University of Maringá, Maringá City, Brazil \\ ${ }^{3}$ Federal Rural University of Amazônia, Parauapebas City, Brazil \\ ${ }^{4}$ Federal University of Uberlândia, Monte Carmelo City, Brazil \\ Correspondence: Antônio Augusto Nogueira Franco, Federal Institute of Pará, Paragominas City, Brazil. Tel: \\ 55-44-99818-4567. E-mail: antonio.franco@ifpa.edu.br
}

Received: June 17, $2018 \quad$ Accepted: August 10, $2018 \quad$ Online Published: October 15, 2018

doi:10.5539/jas.v10n11p138 URL: https://doi.org/10.5539/jas.v10n11p138

The research is financed by National Council for Scientific and Technological Development-CNPq, Coordination of Improvement of Higher Education Personnel-CAPES, and Fundação Araucária.

\begin{abstract}
The aims of study were to evaluate the effect of sowing time in summer season on agronomic characteristics of sweet corn grown in summer season in Northwest Paraná, Brazil. The experiments were conducted in 2011, and 2012, in both years, the sowing was carried out on ST1: 09/05; ST2: 09/19; ST3: 10/03; ST4: 10/17, and ST5: 10/31. The experimental design was a randomized block design in a $5 \times 2$ factorial scheme, consisting of sowing time and two corn hybrids, with four replicates. The evaluated variables were plant height, leaf area index and yield of commercial ears, in which the effects of sowing times were studied through regression analysis, and effects of hybrids and agricultural years were studied by F-test. Sowing times promoted reductions in phenology of hybrids, but did not provide variations in degree-days accumulation by hybrids. The maximum leaf area index (3.82) was estimated for 10/04. In year 2011, the maximum plant height $(2.17 \mathrm{~m})$ and yield $\left(13.0 \mathrm{Mg} \mathrm{ha}^{-1}\right) \mathrm{were}^{-1}$ estimated for 10/06, and 10/03, respectively. While, in year 2012, the maximum height (2.22 m) and yield (12.85 $\mathrm{Mg} \mathrm{ha}^{-1}$ ) were obtained on 10/09 and 10/11, respectively. The hybrid RB6324 showed greater yield potential, independent of year.
\end{abstract}

Keywords: Zea mays L., climatic factors, physiology, special corn

\section{Introduction}

Sweet corn is characterized by presence of genes that block the conversion of sugars to starch in endosperm, resulting in accumulation of high sugar content (Okumura et al., 2014), and low starch content (Souza et al., 2013). The main food uses of sweet corn are canned and "in natura" consumption and, after harvesting, vegetative part can be used for silage production, destined for animal feed, directed perfectly at family farming (Pereira Filho \& Teixeira, 2016).

Although sweet corn has increased interest in Brazil and World, little emphasis has been placed on its management (Souza et al., 2013; Okumura et al., 2014), with farmers being directed to use the recommendations for common maize (Williams II, 2008). However, agronomic practices differ markedly from those recommended for common maize, including stepped planting (Pereira Filho \& Teixeira, 2016), shorter time interval for harvesting and reduction of grain filling period (Franco et al., 2016). Thus, the time that sweet corn is exposed to climatic factors is different from corn grain and, considering that Zea mays L., is strongly influenced by environmental factors (Tsimba, Edmeades, Millner, \& Kemp, 2013a; Marques et al., 2015).

Moreover, in climate change scenarios (Liu, Hubbard, Lin, \& Yang, 2013), the negative effects under sweet corn crop are mitigated by changes in sowing time (Waha et al., 2013), selecting periods in which current climatic conditions can be optimized (Silva, Ferreira, Andrade, \& Araujo, 2010), reflecting directly on the incidence of 
pests (Obopile, Hammond, \& Thomison, 2013), severity of diseases (Blandino, Reyneri, \& Vanara, 2009), in vegetative (Tsimba, Edmeades, Millner, \& Kemp, 2013b), and reproductive development (Gaile, 2012). According to Costa, Souza, Lima, and Cardoso (2010) the use of genotypes adapted with a development cycle proportional to new crop seasons, complement the choices promoting success in current climate scenario.

Research that indicates the recommendation of the best sowing season and suitable genotypes (Gaile, 2012; Waha et al., 2013; Tsimba et al., 2013a), promotes the constant increase of maize yields (J. Wang, E. Wang, Yang, Zhang, \& Yin, 2012). However, these scientific studies have not included sweet corn (Z. H. Khan, Khalil, M. Y. Khan, Israr, \& Basir, 2011).

The knowledge of information contributes to increase the sweet corn yield (Souza et al., 2013, Franco et al., 2016). It is extremely important to have seen the increase in world population and demand for food (Liu et al., 2013), providing options for agricultural diversification and strengthening of family agriculture (Pereira Filho \& Teixeira, 2016), as well as climate change. The aims of study were to evaluate the effect of sowing time (ST) in summer season on agronomic characteristics of sweet corn grown in summer season in Northwest Paraná, Brazil.

\section{Material and Methods}

\subsection{Study Site}

The experiments were conducted at Experimental Farm of State University of Maringá, located in Maringá city,

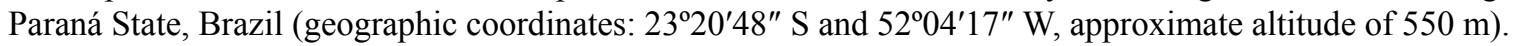

The climate of Northwestern Paraná, according to the Köppen classification, is the Cfa type, defined as humid temperate climate with hot summer (Peel, Finlayson, \& McMahon, 2007), with average temperature in the coldest month lower than $18^{\circ} \mathrm{C}$ (mesothermic), and the average temperature in the warmest month over $22{ }^{\circ} \mathrm{C}$. The summers are warm, frosts are infrequent and rainfall tends to concentrate in summer season, but without a specific dry season. Data of temperature, solar radiation, photoperiod, rainfall and supplementary irrigation that occurred during each one of the agricultural years are showed in Figure 1. Data from maximum, average and minimum temperatures were used to determine the thermal amplitude (Figure 1) and accumulated thermal sum. 

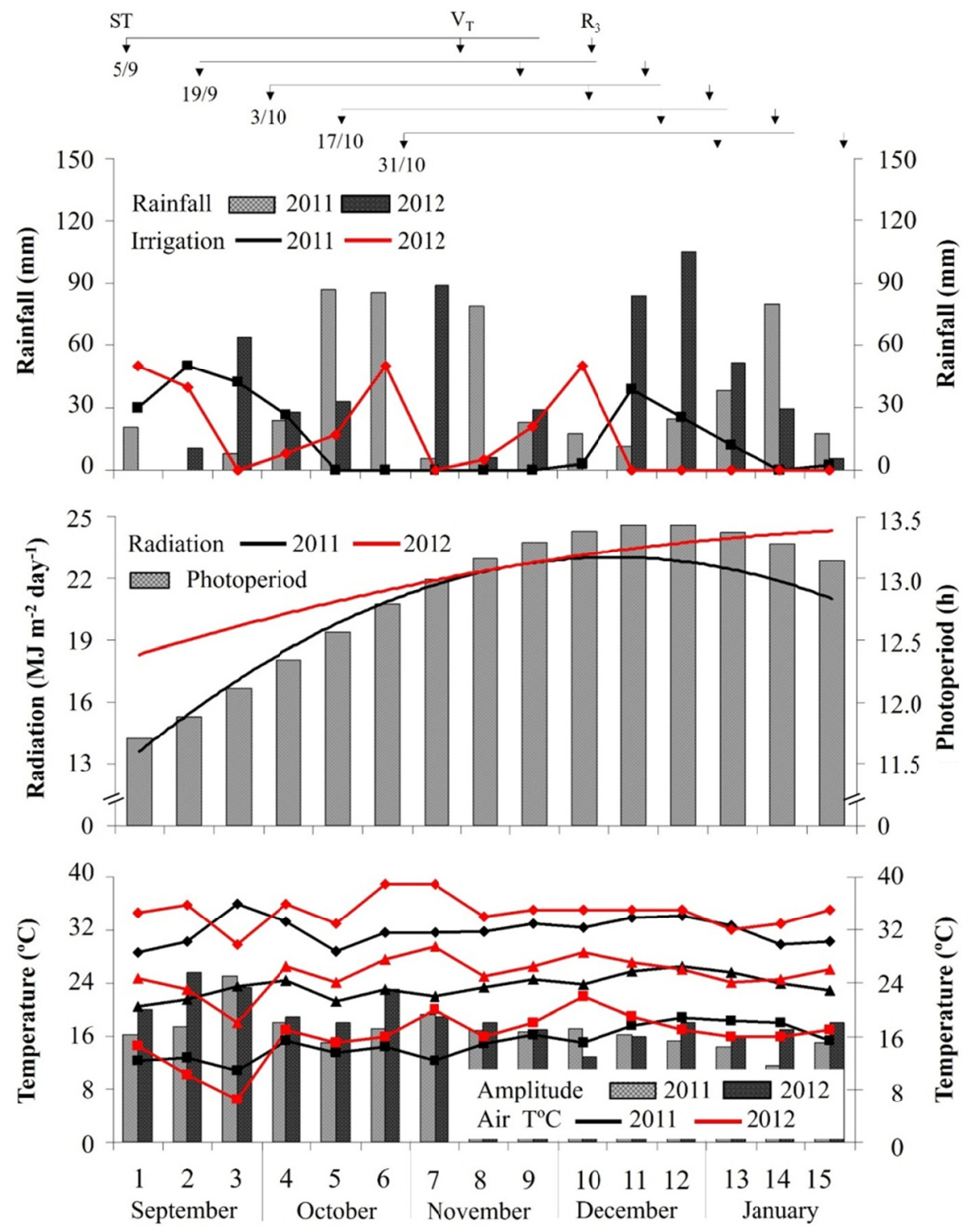

Periods of ten days after sowing

Figure 1. Rainfall, supplemental irrigation, solar radiation, photoperiod, maximum, minimum, average air temperature ( Air T $^{\circ} \mathrm{C}$ ) and thermal amplitude in the summer season of 2011 and 2012, in Maringá city, Brazil Note. Phenological stages: $\mathrm{V}_{\mathrm{T}}=$ tasseling; $\mathrm{R}_{3}=$ milky grain (Ritchie et al., 1993).

Sowing times: ST1 (09/05), ST2 (09/19), ST3 (10/03), ST4 (10/17), and ST5 (10/31).

Equivalence of periods of ten days: 1 (09/5-10), 2 (09/11-20), 3 (09/21-30), 4 (10/1-10), 5 (10/11-20), 6 (10/21-31), 7 (11/1-10), 8 (11/11-20), 9 (11/21-31), 10 (12/1-10), 11 (12/11-20), 12 (12/21-31), 13 (01/1-10), 14 (01/11-20), and $15(01 / 21-31)$.

The accumulated thermal sum by sweet corn plants was determined by thermal sum daily units, according to Franco et al. (2016), using the modified expression:

$$
\mathrm{ST}=\sum_{\mathrm{n}=1}^{\mathrm{N}} \mathrm{GD}\left(\frac{\mathrm{T}_{\max }+\mathrm{T}_{\min }}{2}\right)-\mathrm{T}_{\mathrm{b}}
$$

where, ATS $=$ accumulated thermal sum $\left({ }^{\circ} \mathrm{C}\right.$ day $\left.^{-1}\right) ; \Sigma \mathrm{TS}=$ thermal sum daily $\left({ }^{\circ} \mathrm{C}\right.$ day $\left.{ }^{-1}\right) ; \mathrm{N}=$ number of days; Tmax $=$ maximum air temperature $\left({ }^{\circ} \mathrm{C}\right)$; Tmin $=$ minimum air temperature $\left({ }^{\circ} \mathrm{C}\right) ; \mathrm{Tb}=$ base air temperature of the corn crop, for which $10^{\circ} \mathrm{C}$ was adopted. 
The soil from experimental area was classified as dystroferric Red Nitissol (Embrapa, 2013), clayey texture (clay: $520 \mathrm{~g} \mathrm{~kg}^{-1}$; silt: $140 \mathrm{~g} \mathrm{~kg}^{-1}$; sand: $340 \mathrm{~g} \mathrm{~kg}^{-1}$ ) and the results of the chemical analyses of the main characteristics of soil material from 0.0 to $0.20 \mathrm{~m}$ and 0.20 to $0.40 \mathrm{~m}$ layers are shown in Table 1 .

Table 1. Chemical analyses of soil material from experimental plots from layers 0-0.20 and 0.20-0.40 m of depth, in the summer season of 2011 and 2012 agricultural years

\begin{tabular}{|c|c|c|c|c|c|c|c|c|c|c|}
\hline Years & $\mathrm{pH}$ & $* * * \mathrm{C}$ & $* \mathrm{P}$ & $* \mathrm{~K}^{+}$ & $* * \mathrm{Ca}^{+2}$ & $* * \mathrm{Mg}^{+2}$ & $* * \mathrm{Al}^{+3}$ & SB & CTC & $\mathrm{V}$ \\
\hline & $\mathrm{CaCl}_{2}$ & $\mathrm{~g} \mathrm{dm}^{-3}$ & $\mathrm{mg} \mathrm{dm}{ }^{-3}$ & \multicolumn{6}{|c|}{ |----------------------------- $\mathrm{cmol}_{\mathrm{c}} \mathrm{dm}^{-3}$-------------------------- } & $--\%$ \\
\hline \multicolumn{11}{|c|}{ Layers $0.00-0.20 \mathrm{~m}$} \\
\hline 2011 & 5.6 & 9.21 & 25.80 & 0.36 & 4.20 & 1.50 & 0.00 & 3.17 & 9.23 & 65.66 \\
\hline 2012 & 5.1 & 13.81 & 22.40 & 0.29 & 4.05 & 1.50 & 0.00 & 5.84 & 9.81 & 59.53 \\
\hline \multicolumn{11}{|c|}{ Layers $0.20-0.40 \mathrm{~m}$} \\
\hline 2011 & 5.6 & 9.59 & 3.90 & 0.18 & 4.20 & 1.54 & 0.00 & 5.92 & 9.09 & 65.13 \\
\hline 2012 & 5.0 & 12.28 & 17.50 & 0.22 & 4.02 & 1.38 & 0.00 & 5.62 & 9.59 & 58.60 \\
\hline
\end{tabular}

Note. * Mehlich 1; ** $\mathrm{KCl} 1 \mathrm{~mol} \mathrm{~L}^{-1} ;{ }^{* * *}$ Walkley-Black.

The installation and conduction of experiments occurred during the rainy season, in summer season of 2011/12, and 2012/13 agricultural years. In both years, sowing was carried out on same dates (ST1: 09/05; ST2: 09/19; ST3: 10/03; ST4: 10/17, and ST5: 10/31), after maize cultivation in 2011 and after oats in 2012.

\subsection{Treatments, Experimental Design and Plot}

The experiments was conducted in randomized complete block design, in a factorial $5 \times 2$ in two agricultural years (2011 and 2012), with four replications. The factors studied were: i) Factor A: five sowing time (ST1: 09/05; ST2: 09/19; ST3: 10/03; ST4: 10/17, and ST5: 10/31), and ii) Factor B: two sweet corn simple hybrids (Tropical Plus and RB6324). Each experimental plot was constituted of five rows of plants with $6.0 \mathrm{~m}$ in length, spaced by $0.9 \mathrm{~m}$, totaling a total area of $27 \mathrm{~m}^{2}$ and an experimental area of $13.5 \mathrm{~m}^{2}$ (Marques et al., 2015).

\subsection{Crop Management}

The sowing density used was 5 plants $\mathrm{m}^{-1}$ in no-tillage system in order to reach a population density of approximately 55.500 plants ha $^{-1}$ (Souza et al., 2013). Management of fertilizing was according to Okumura et al. (2014) and all other cultivation techniques used were those recommended for the corn crop, including irrigation management (Marques et al., 2015).

\subsection{Evaluated Characteristics}

The phytotechnical evaluations of growth (plant height, and leaf area index) were assessed in five randomly selected plants in each plot at VT (Ritchie, Hanway, \& Benson, 1993). Plant height was measured on the stem length from the soil surface to the base of the male inflorescence (Moreira et al., 2018). The leaf area index (LAI) was obtained by measuring the length (L) and the width (W) of all the leaves in each plant. The leaf area (LA) was calculated by the following equation: $\mathrm{LA}=0.75 \times \mathrm{L} \times \mathrm{W}$, later, the LAI was calculated from the LA measures by the equation (Sangoi et al., 2007):

$$
\mathrm{LAI}=\frac{\mathrm{LA}}{\mathrm{S}_{1} \times \mathrm{S}_{2}}
$$

where, $S_{1}$ and $S_{2}$ refer to the spacing in meter $(\mathrm{m})$ between plants and between rows, respectively.

The sweet corn ears were harvested at R3 (Ritchie et al., 1993), in milky grain (Pereira et al., 2009). At this moment was assessed the yield of dehusked marketable ear (length greater than $15 \mathrm{~cm}$, diameter greater than 3 $\mathrm{cm}$ and free from pests), according to Albuquerque, Von Pinho, Borges, Souza Filho, and Fiorini (2008).

\subsection{Data Analysis}

The experimental data from each one of the agricultural years were assessed using the Shapiro-Wilks and Levene tests $(\mathrm{P} \leq 0.01)$ to verify the normality and homoscedasticity waste. Later, the data were subjected to an individual analysis of variance, and was verified whether the relationships between the residual mean squares were lower than 7:1. Finally, the data were submitted to analysis of variance with application of F-test $(\mathrm{P} \leq 0.05)$, and then partitioning as necessary (Barbin, 2013). The sowing time effects were studied by polynomial regression analysis and the effects of the hybrids and years were studied by the F-test $(\mathrm{P} \leq 0.05)$ of the analysis of variance. The statistical procedures were carried out by SISVAR statistical software (Ferreira, 2011). 


\section{Results and Discussion}

\subsection{Climatic Characteristics}

The rainfall observed in summer season of agricultural years of 2011 and 2012 were insufficient for water requirement in maize, with values lower than $500 \mathrm{~mm}$ (Silva et al., 2010). In 2011, rainfall was mainly concentrated in October and November and accumulated rainfall were 336, 340, 350, 317, and $278 \mathrm{~mm}$, at sowing times: ST1 $(249=09 / 05)$; ST2 $(263=09 / 19)$; ST3 $(277=10 / 03)$; ST4 $(291=10 / 17)$; and ST5 $(305=$ 10/31), respectively (Figure 1). While, in 2012 occurred regularity of rainfall in December and January, and accumulated rainfall were $260,286,242,380$, and $394 \mathrm{~mm}$, at sowing times ST1, ST2, ST3, ST4, and ST5, respectively (Figure 1). Thus, in both years, supplementary irrigation was important to provide the amount of water required for sweet corn (Silva et al., 2010).

Solar radiation was most intense in agricultural year of 2012 (Figure 1). In relation to photoperiod, verified increases until December, followed by decreases (Figure 1). The photoperiod is a factor dependent on day and latitude, so the same is common in every year.

Temperatures showed quadratic behavior, and maximum values were observed in October, November and December (Figure 1), in which the agricultural year of 2012 was warmer and promoted higher thermal amplitudes compared to 2011 (Figure 1).

\subsection{Phenological Cycle and Accumulated Thermal Sum}

Delays in sowing times promoted reductions in phenological cycle of sweet corn hybrids, RB6324 and Tropical Plus, in both agricultural years (Figure 2). Sowing times did not provide significant variations in degree-days accumulation by RB6324 and Tropical Plus hybrids (Figure 2). Similar result were verified by Williams II (2008), and Franco et al. (2016), studying the effect of sowing time on sweet corn, observed that number of days between emergence and tasseling stage varied with sowing time, and little influence had the thermal time.

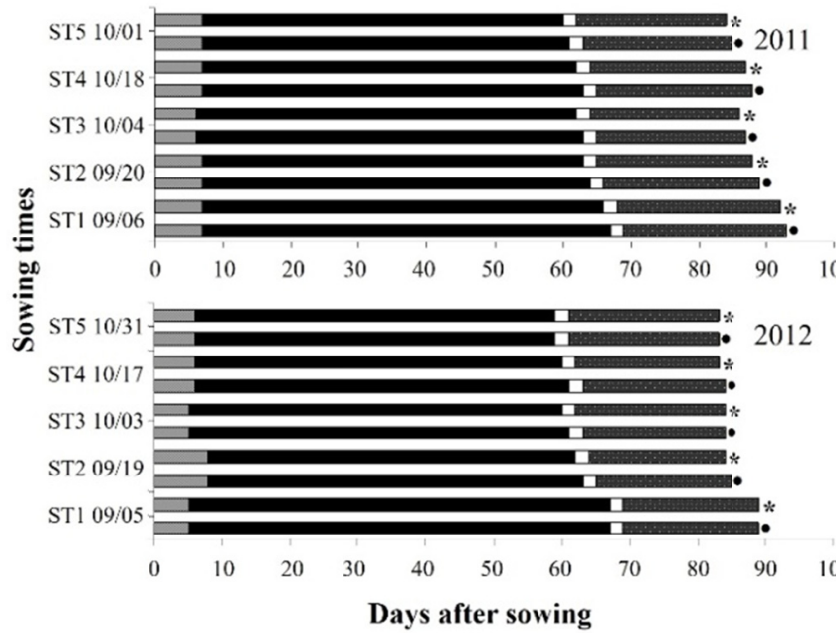

Days after sowing

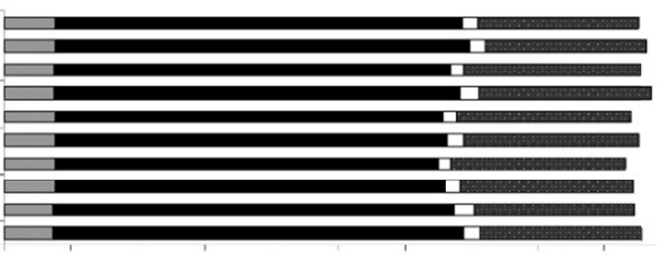

$\begin{array}{llllllllll}125 & 250 & 375 & 500 & 625 & 750 & 875 & 1000 & 1125 & 1250\end{array}$

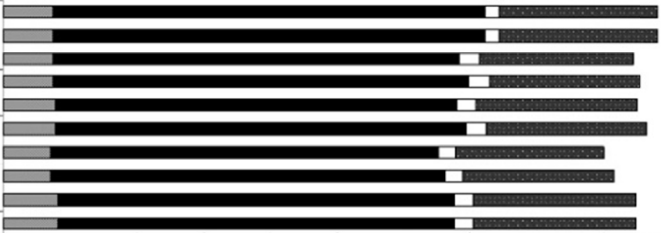

$\begin{array}{llllllllllll}100 & 0 & 125 & 250 & 375 & 500 & 625 & 750 & 875 & 1000 & 1125 & 1250\end{array}$ Accumulated thermal sun

$\square \mathrm{VE} \quad \mathrm{V}_{\mathrm{T}} \square \mathrm{R}_{1} \quad \mathrm{R}_{3} \bullet$ Tropical Plus $* \mathrm{RB} 6324$

Figure 2. Days after sowing and accumulated thermal sum till emergence $(\mathrm{VE})$, tasseling $\left(\mathrm{V}_{\mathrm{T}}\right)$, silking $\left(\mathrm{R}_{1}\right)$ and milky grain $\left(\mathrm{R}_{3}\right)$ for two sweet corn hybrids, in the summer season of 2011 and 2012, in Maringá, Northwest of Paraná State, Brazil

This fact is explained because maize needs an accumulation of degrees-days to complete the stages of development (Tsimba et al., 2013b; Marques et al., 2015). The thermal unit is directly proportional to temperature (Gaile, 2012). Thus, in high temperatures the daily thermal units are larger, justifying the reduction of the cycle, once has completed the accumulation of thermal sum required (Franco et al., 2016).

According to Soler, Sentelhas, and Hoogenboom (2005), the thermal energy describes the development rate with greater accuracy compared to time expressed in days, independent of time and place of cultivation, and being observed in number of days identified between ST2 (09/19) and emergency (VE) in the agricultural year of 2012 
(Figure 2), period which the lowest temperatures were recorded (Figure 1). Gaile (2012), studying the effect of sowing time on maize development obtained negative correlations between temperature and number of days until germination.

\subsection{Joint Analysis of Variance of Experiments}

The analysis of joint variance indicated a significant effect $(\mathrm{P}<0.05)$ for sowing times and agricultural years in evaluated variables. While, hybrid factor was significant only for yield of commercial ears (Table 2).

Table 2. Summary of the variance analysis of sweet corn phenotypic characteristics (plant height- $\mathrm{PH}$, leaf area index-LAI and yield of marketable ear-Yield) in the summer season of 2011 and 2012, in Maringá city, Northwest Region of Paraná State, Brazil

\begin{tabular}{|c|c|c|c|c|}
\hline \multirow{2}{*}{ Font of variations } & \multirow{2}{*}{$\mathrm{DF}$} & \multicolumn{3}{|c|}{ Mean square } \\
\hline & & $\mathrm{PH}(\mathrm{m})$ & LAI $\left(\mathrm{m}^{2} \mathrm{~m}^{-2}\right)$ & Yield $\left(\mathrm{Mg} \mathrm{ha}^{-1}\right)$ \\
\hline Times (T) & 4 & $0.207 *$ & $0.418^{*}$ & $20.415^{*}$ \\
\hline Hybrids (H) & 1 & $0.008^{\mathrm{ns}}$ & $0.315^{\mathrm{ns}}$ & $6.401 *$ \\
\hline Years (Y) & 1 & $0.135^{*}$ & $2.285^{*}$ & $5.762 *$ \\
\hline $\mathrm{T} \times \mathrm{H}$ & 4 & $0.007^{\mathrm{ns}}$ & $0.271^{\mathrm{ns}}$ & $2.685^{*}$ \\
\hline $\mathrm{T} \times \mathrm{Y}$ & 4 & $0.010^{*}$ & $0.094^{\mathrm{ns}}$ & $6.438^{*}$ \\
\hline $\mathrm{H} \times \mathrm{Y}$ & 1 & $0.003^{\mathrm{ns}}$ & $0.005^{\mathrm{ns}}$ & $3.172^{\mathrm{ns}}$ \\
\hline $\mathrm{T} \times \mathrm{H} \times \mathrm{Y}$ & 4 & $0.003^{\mathrm{ns}}$ & $0.010^{\mathrm{ns}}$ & $4.333^{*}$ \\
\hline Blocks/Years & 6 & 0.004 & 0.010 & 1.760 \\
\hline Residue & 54 & 0.004 & 0.111 & 0.951 \\
\hline General average & & 2.07 & 3.70 & 11.72 \\
\hline $\mathrm{CV}(\%)$ & & 2.93 & 8.99 & 8.32 \\
\hline
\end{tabular}

Note. ${ }^{*}$ significant; ${ }^{\text {ns }}$ not significant, in $5 \%$ probability level, by F-test.

For the interactions, analysis of variance showed dependence $(\mathrm{P}<0.05)$ between the factors in times $\mathrm{x}$ hybrids interaction and in triple interaction for yield, showing that this variable is related to sowing times, hybrids, and years. However, for sowing times $x$ years interaction the analysis showed independence $(P>0.05)$ among the factors for LAI variable. The analysis did not indicate a significant effect $(P>0.05)$ on hybrids $\times$ years interaction in any studied variable (Table 2).

\subsection{Growth and Plant Development Characteristics}

Plant height $(\mathrm{PH})$, and leaf area index (LAI) varied with sowing times showing quadratic behavior. In 2011, maximum plant height $(2.17 \mathrm{~m})$ was estimated for Julian $279(10 / 06)$; for the year 2012 the maximum plant height (2.22 m) was obtained in sowing done on Julian 283 (10/09) in average of hybrids (RB6324, and Tropical Plus). While, maximum LAI (3.82) was estimated for Julian 277 (10/04), in average of hybrids hybrids (RB6324, and Tropical Plus) and years (2011, and 2012) (Figure 3). 

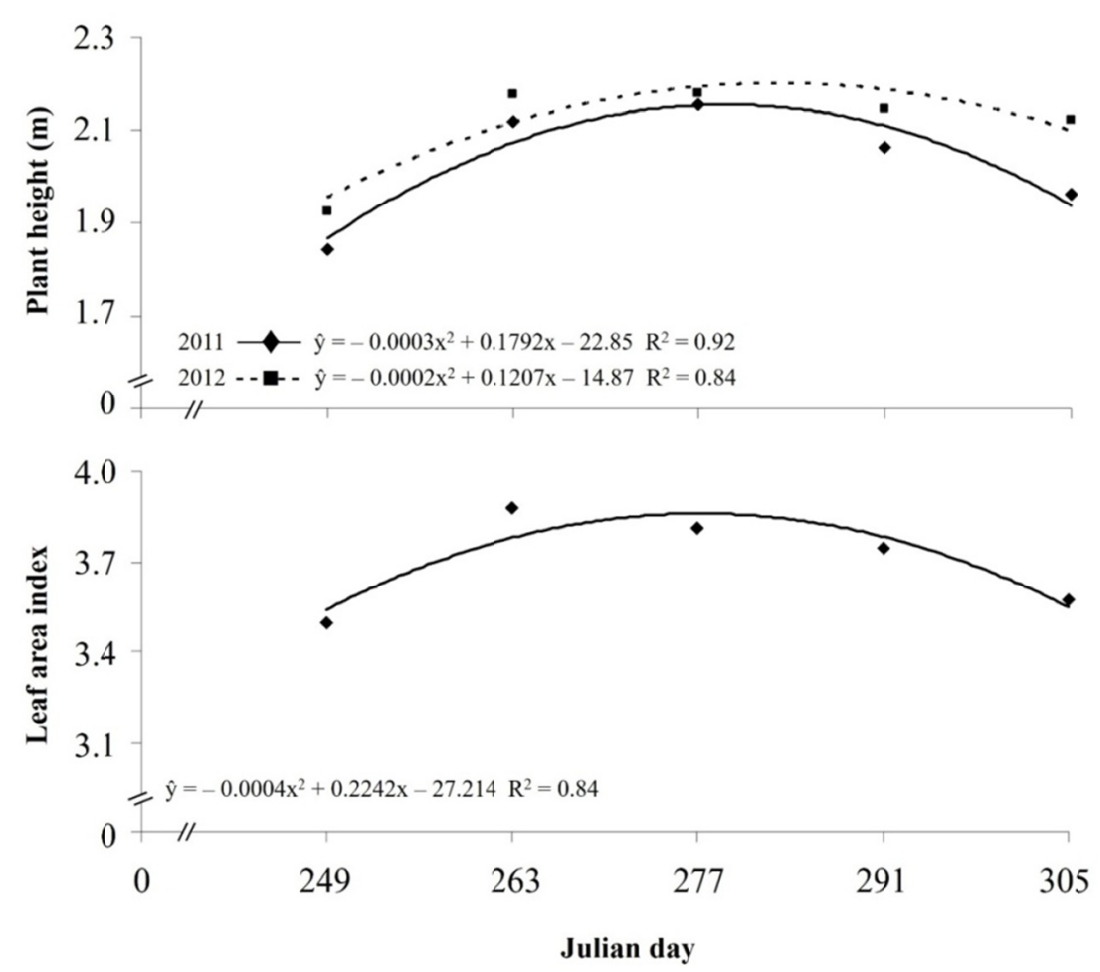

Figure 3. Average plant height and leaf area index of two sweet corn hybrids (Tropical Plus and RB6324) in relation to the sowing time (ST) in the summer season of 2011 and 2012, in Maringá, Northwest of Paraná State, Brazil

Note. $\mathrm{ST}_{1}=249(09 / 05) ; \mathrm{ST}_{2}=263(09 / 19) ; \mathrm{ST}_{3}=277(10 / 03) ; \mathrm{ST}_{4}=291(10 / 17)$ and $\mathrm{ST}_{5}=305(10 / 31)$

The year 2012 promoted favorable climatic conditions for growth and development of sweet corn plants in most of sowing times studied (Table 3). Although corn growth is strongly correlated with genetic trait (Gaile, 2012), greater plant development in 2012 compared to year 2011 (Table 3), probably occurred due to temperature and solar radiation (Figure 1), climatic factors of great influence on corn growth and development (Brachtvogel, Pereira, Cruz, \& Bicudo, 2009).

Table 3. Average plant height, and leaf area index of two sweet corn hybrids (Tropical Plus, and RB6324) in two years (2011, and 2012) in five sowing time (ST1: 09/05; ST2: 09/19; ST3: 10/03; ST4: 10/17, and ST5: 10/31), in summer season in Maringá city, Brazil

\begin{tabular}{lllllll}
\hline Years & $\mathrm{ST}_{1}$ & $\mathrm{ST}_{2}$ & $\mathrm{ST}_{3}$ & $\mathrm{ST}_{4}$ & $\mathrm{ST}_{5}$ & LAI \\
\hline & $-----------------\mathrm{m}^{2} \mathrm{~m}^{-2}---$ \\
2011 & $1.84 \mathrm{~b}^{*}$ & $2.12 \mathrm{a}$ & $2.16 \mathrm{a}$ & $2.06 \mathrm{~b}$ & $1.96 \mathrm{~b}$ & $3.53 \mathrm{~b}$ \\
2012 & $1.93 \mathrm{a}$ & $2.18 \mathrm{a}$ & $2.18 \mathrm{a}$ & $2.15 \mathrm{a}$ & $2.12 \mathrm{a}$ & $3.87 \mathrm{a}$
\end{tabular}

Note. * Means followed by the same letter in column are not different by $\mathrm{F}$-test $(\mathrm{P} \leq 0.05)$.

Temperature is main factor that influences the physiological mechanisms of maize (Gaile, 2012). The agricultural year of 2012 showed the highest temperature compared to 2011 (Figure 1), positively influencing the photosynthetic process of sweet corn (Tollenaar, 1989), resulting in a greater accumulation of photoassimilates in leaves (Andrade, Uhart, \& Cirilo, 1993).

In year of 2012, verified greater thermal amplitudes compared to 2011 (Figure 1). According to Lozada and Angelocci (1999), corn development shows a linear relationship with thermal amplitude, since this is inversely proportional to increase in cellular respiration, promoting a higher balance of photoassimilates (Edreira \& Otegui, 2012). 


\subsection{Production Component Characteristics}

The analysis of triple interaction (times $\times$ hybrids $\times$ years) for variable yield of dehusked marketable ears allowed to adjust the quadratic polynomial model (Figure 4). In 2011 , maximum yields were $13.2 \mathrm{Mg} \mathrm{ha}^{-1}$ (RB6324) and $12.8 \mathrm{Mg} \mathrm{ha}^{-1}$ (Tropical Plus), both estimated for Julian $276(10 / 03)$. While in 2012, maximum yields obtained by RB6324 and Tropical Plus hybrids were 13.1 $\mathrm{Mg} \mathrm{ha}^{-1}$, and $12.6 \mathrm{Mg} \mathrm{ha}^{-1}$ estimated for Julian days $282(10 / 08)$, and $288(10 / 15)$, respectively (Figure 4$)$.

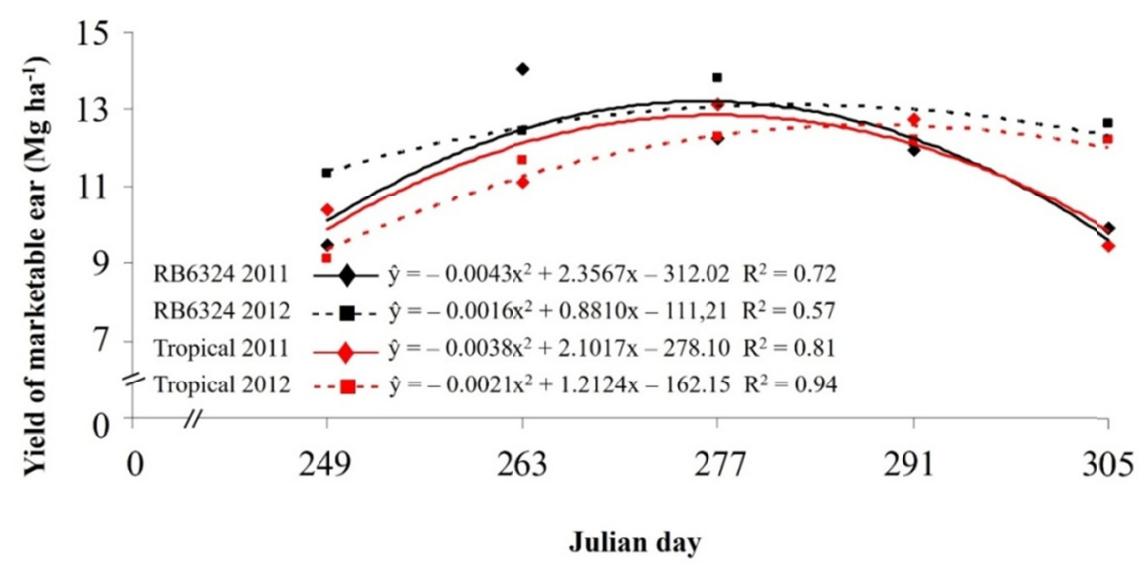

Figure 4. Yield of dehusked marketable ears of two sweet corn hybrids in relation to the sowing time (ST) in the summer season of 2011 and 2012, in Maringá city, Brazil

Note. Sowing times (ST): $\mathrm{ST}_{1}=09 / 05 ; \mathrm{ST}_{2}=09 / 19 ; \mathrm{ST}_{3}=10 / 03 ; \mathrm{ST}_{4}=10 / 17$ and $\mathrm{ST}_{5}=10 / 31$.

Other studies founded that anticipating or delaying sowing time negatively influenced sweet corn production (Williams II, 2008; Khan et al., 2011). Corn yield is determined by genetic potential and environment (Córdova \& Carreño, 2012), so the results obtained, can be explained by climatic conditions having been restrictive with the delay of sowing time (Figure 1).

Tsimba et al. (2013a) studying the effect of sowing seasons $(09 / 19,10 / 12,11 / 02$ and 11/23) on corn in three sites in New Zealand $\left(37.86^{\circ} \mathrm{S}\right.$ and $175.32^{\circ} \mathrm{E}$ at $50 \mathrm{~m} ; 37.98^{\circ} \mathrm{S}$ and $175.32^{\circ} \mathrm{E}$ at $84 \mathrm{~m}$; and $40.38^{\circ} \mathrm{S}$ and $175.58^{\circ} \mathrm{E}$ at $18 \mathrm{~m}$ ) obtained quadratic responses for LAI, total biomass and yield, in which the maximum technical efficiency were obtained in sowing conducted at end October and early November, in summer season.

In early sowing time, before spring season (August to September in southern hemisphere), there is lower radiation and temperature in early stages of plant development (Andrade et al., 1993), reducing seeds germination (Williams II, 2008), growth and initial development of sweet corn (Gaile, 2012; Tsimba et al., 2013b), resulting in formation of smaller leaf area per plant and smaller plants (Sangoi, Schmit, \& Zanin, 2007), promoting limitation of photoassimilates (Tsimba et al., 2013a). While, sowing performed at end of recommended sowing time the production components are limited because the grain filling stage coincides with a significant deterioration of environmental conditions (Marques et al., 2015; Franco et al., 2016).

The RB6324 hybrid, in general, showed a higher productive potential $(\mathrm{P}>0.05)$ for variable yield of dehusked marketable ears, independent of years (Table 4). This result is corroborated by Okumura et al. (2014) studying the same hybrids in summer in three agricultural years. 
Table 4. Yield of dehusked marketable ears of two sweet corn hybrids in two years in five sowing time (ST), in summer season in Maringá city, Brazil

\begin{tabular}{|c|c|c|c|c|c|c|c|c|c|c|}
\hline \multirow{2}{*}{ Hybrids } & \multicolumn{5}{|c|}{2011} & \multicolumn{5}{|c|}{2012} \\
\hline & $\mathrm{ST}_{1}$ & $\mathrm{ST}_{2}$ & $\mathrm{ST}_{3}$ & $\mathrm{ST}_{4}$ & $\mathrm{ST}_{5}$ & $\mathrm{ST}_{1}$ & $\mathrm{ST}_{2}$ & $\mathrm{ST}_{3}$ & $\mathrm{ST}_{4}$ & $\mathrm{ST}_{5}$ \\
\hline Tropical & $10.37 \mathrm{a}^{*}$ & $11.11 \mathrm{~b}$ & $13.12 \mathrm{a}$ & $12.75 \mathrm{a}$ & $9.48 \mathrm{a}$ & $9.14 b$ & $11.69 \mathrm{a}$ & $12.29 \mathrm{~b}$ & $12.20 \mathrm{a}$ & $12.20 \mathrm{a}$ \\
\hline RB6324 & $9.48 \mathrm{a}$ & $14.05 \mathrm{a}$ & $12.25 \mathrm{a}$ & $11.96 \mathrm{a}$ & $9.92 \mathrm{a}$ & $11.33 \mathrm{a}$ & $12.44 \mathrm{a}$ & $13.80 \mathrm{a}$ & $12.15 \mathrm{a}$ & $12.62 \mathrm{a}$ \\
\hline Years & \multicolumn{5}{|c|}{ TROPICAL } & \multicolumn{5}{|c|}{ RB6324 } \\
\hline 2011 & $10.37 \mathrm{a}$ & $11.11 \mathrm{a}$ & $13.12 \mathrm{a}$ & $12.75 \mathrm{a}$ & $9.48 b$ & $9.48 b$ & $14.05 \mathrm{a}$ & $12.25 b$ & $11.96 \mathrm{a}$ & $9.92 b$ \\
\hline 2012 & $9.14 \mathrm{a}$ & $11.69 \mathrm{a}$ & $12.29 \mathrm{a}$ & $12.20 \mathrm{a}$ & $12.20 \mathrm{a}$ & $11.33 \mathrm{a}$ & $12.44 \mathrm{~b}$ & $13.80 \mathrm{a}$ & $12.15 \mathrm{a}$ & $12.62 \mathrm{a}$ \\
\hline
\end{tabular}

Note. * Means followed by the same letter in the column are not different by $\mathrm{F}$ test $(\mathrm{P} \leq 0.05)$.

Sowing times (ST): $\mathrm{ST}_{1}=09 / 05 ; \mathrm{ST}_{2}=09 / 19 ; \mathrm{ST}_{3}=10 / 03 ; \mathrm{ST}_{4}=10 / 17$ and $\mathrm{ST}_{5}=10 / 31$.

The year 2012 was better for sweet corn production, independent of hybrids adopted (Table 4). This result can be explained, among other factors discussed, by greater availability of radiation in 2012 compared to 2011 (Figure 1), because solar radiation is one of most influential climatic factors on maize crop (Brachtvogel et al., 2009), promoting excitation of chlorophyll molecules, initiating energy flow necessary for photosynthesis (Taiz \& Zeiger, 2013). According to Fageria (1998), solar radiation incident on terrestrial atmosphere is main source of energy for physiological and biochemical processes that occur in plants. For these reasons, maize yield follows a relation directly proportional to radiation, not occurring water restrictions (Bergamaschi et al., 2006).

The climatic conditions observed in 2011 resulted in lower plant development, represented by low plant height (2.03m in 2011, and 2.11m in 2012) and LAI of 3.53 (2011) compared to 3.87 (2012) (Table 3). Although, yield is dependent on photosynthetic production only after flowering (Lee \& Tollenaar, 2007), leaf area is main contribution to spike development (Subedi \& Ma, 2005), thus, growth and LAI relates directly with yield (Córdova \& Carreño, 2012).

In year of 2011, plants showed a smaller canopy capable of potentiating the solar radiation (Subedi \& Ma, 2005) factor determining of yield (Tsimba et al., 2013a), promoting lower photoassimilate production and, finally, lower translocation of these to grain filling (Duete, Muraoka, Silva, Trivelin, \& Ambrosano, 2008).

\section{Conclusions}

Sowing times influenced the growth and yield of sweet corn. The RB6324 hybrid showed higher yield of dehusked marketable ears compared to Tropical Plus hybrid. The use of irrigation was essential in all sowing times and years of study.

\section{Acknowledgements}

We thank the National Council for Scientific and Technological Development (CNPq/Brazil) for Productivity in Research Scholarship and Fundação Araucária by financial support for this research work. We also appreciate the scholarship from Coordination of Improvement of Higher Education Personnel (CAPES/Brazil).

\section{References}

Albuquerque, C. J. B., Von Pinho, R. G., Borges, I. D., Souza Filho, A. X., \& Fiorini, I. V. A. (2008). Performance of experimental and commercial hybrids of maize for the production of green maize. Ciência e Agrotecnologia, 32, 768-775. https://doi.org/10.1590/S1413-70542008000300010

Andrade, F. H., Uhart, S. A., \& Cirilo, A. (1993). Temperature affects radiation use efficiency in maize. Field Crops Research, 32, 17-25. https://doi.org/10.1016/0378-4290(93)90018-I

Barbin, D. (2013). Planejamento e análise estatística de experimentos agronômicos (p. 214). Porto Alegre: Macenas.

Bergamaschi, H., Dalmago, G. A., Comiran, F., Bergonci, J. I., Müller, A. G., França, S., ... Pereira, P. G. (2006). Water deficit and yield in maize crop. Pesquisa Agropecuária Brasileira, 41, 243-249. https://doi.org/ 10.1590/S0100-204X2006000200008

Blandino, M., Reyneri, A., \& Vanara, F. (2009). Effect of sowing time on toxigenic fungal infection and mycotoxin contamination of maize kernels. Journal of Phytopathology, 157, 7-14. https://doi.org/10.1111/ j.1439-0434.2008.01431.x 
Brachtvogel, E. L., Pereira, F. R. S., Cruz, S. C. S., \& Bicudo, S. J. (2009). Maize plant densities in conventional and equidistant plant spacing. Ciência Rural, 39, 2334-2339. https://doi.org/10.1590/S0103-84782009 005000193

Córdova, N. H., \& Carreño, F. S. (2012). Influence of three planting dates on growth and yield of cereal species grown in tropical conditions. Part I. Maize (Zea mays L.). Cultivos Tropicales, 33, 44-49.

Costa, E. F. N., Souza, J. C., Lima, J. L., \& Cardoso, G. A. (2010). Genotype by environment interaction in different types of maize hybrids. Pesquisa Agropecuária Brasileira, 45, 1433-1440. https://doi.org/10.1590/ S0100-204X2010001200014

Duete, R. R. C., Muraoka, T., Silva, E. C., Trivelin, P. C. O., \& Ambrosano, E. J. (2008). Nitrogen fertilization management and nitrogen $\left({ }^{15} \mathrm{~N}\right)$ utilization by corn crop in Red Latosol. Revista Brasileira de Ciência do Solo, 32, 161-171. https://doi.org/10.1590/S0100-06832008000100016

Edreira, J. I. R., \& Otegui, M. E. (2012). Heat stress in temperate and tropical maize hybrids: differences in crop growth, biomass partitioning and reserves use. Field Crops Research, 130, 87-98. https://doi.org/10.1016/ j.fcr.2012.02.009

Embrapa. (2013). Sistema brasileiro de classificação de solos (p. 353). Brasília: Embrapa.

Fageria, N. K. (1998). Optimizing nutrient use efficiency in crop production. Revista Brasileira de Engenharia Agrícola e Ambiental, 2, 6-16. https:/doi.org/10.1590/1807-1929/agriambi.v02n01p6-16

Ferreira, D. F. (2011). Sisvar: A computer statistical analysis system. Ciência e Agrotecnologia, 35, $1039-1042$. https://doi.org/10.1590/S1413-70542011000600001

Franco, A. A. N., Vidigal Filho, P. S., Scapim, C. A., Okumura, R. S., Marques, O. J., \& Numoto, A. Y. (2016). Effect of sowing time on the growth and yield of sweet corn (Zea mays L.) cultivated during fall-winter period in Subtropical climate. Australian Journal of Crop Science, 10, 831-841. https://doi.org/10.21475/ ajcs.2016.10.06.p7460

Gaile, Z. (2012). Maize (Zea mays L.) response to sowing timing under agro-climatic conditions of Latvia. Zemdirbyste-Agriculture, 99, 31-40.

Khan, Z. H., Khalil, S. K., Khan, M. Y., Israr, M., \& Basir, A. (2011). Selecting optimum planting date for sweet corn in Peshawar, Pakistan. Sarhad Journal of Agriculture, 27, 341-347.

Lee, E. A., \& Tollenaar, M. (2007). Physiological basis of successful breeding strategies for maize grain yield. Crop Science, 47, 202-215. https://doi.org/10.2135/cropsci2007.04.0010IPBS

Liu, Z., Hubbard, K. G., Lin, X., \& Yang, X. (2013). Negative effects of climate warming on maize yield are reversed by the changing of sowing date and cultivar selection in Northeast China. Global Change Biology, 19, 3481-3492. https://doi.org/10.1111/gcb.12324

Lozada, B. I., \& Angelocci, L. R. (1999). Effect of air temperature and soil water availability on the duration of the growing stages and on the yield of a corn hybrid (Zea mays). Revista Brasileira de Agrometeorologia, 7, $37-43$.

Marques, O. J., Vidigal Filho, P. S., Scapim, C. A., Bonato, C. M., Okumura, R. S., Silva, L .I., \& Souza, R. S. (2015). Sowing Time of Popcorn During the Summer Harvest Under Supplemental Irrigation in a Ferralic Nitisol and Subtropical Climate. Australian Journal of Crop Science, 9, 413-423.

Moreira, W. K. O., Borrajo, F. D., Sousa, S. K. A., Cardoso, G. G., Luz, A. L. S., Silva, R. T. L., ... Oliveira Neto, C. F. (2018). Methods of soil management and depths of sowing in corn cultivation. Journal of Agricultural Science, 10, 299-309. https://doi.org/10.5539/jas.v10n6p299

Obopile, M., Hammond, R. B., \& Thomison, P. R. (2013). Interaction among planting dates, transgenic maize, seed treatment, corn rootworm damage and grain yield. Journal of Applied Entomology, 137, 45-55. https://doi.org/10.1111/j.1439-0418.2012.01716.x

Okumura, R. S., Vidigal Filho, P. S., Scapim, C. A., Marques, O. J., Franco, A. A. N., Souza, R. S., \& Reche, D. L. (2014). Effects of nitrogen rates and timing of nitrogen topdressing applications on the nutritional and agronomic traits of sweet corn. International Journal of Food, Agriculture and Environment, 12, 391-398.

Peel, M. C., Finlayson, B. L., \& McMahon, T. A. (2007). Updated world map of the Köppen-Geiger climate classification. Hidrology and Earth System Science, 11, 1633-1644. https://doi.org/10.5194/hess-111633-2007 
Pereira Filho, I. A., \& Teixeira, F. F. (2016). O cultivo do milho-doce. Brasília: Embrapa.

Pereira, A. F., Melo, P. G. S., Pereira, J. M., Assunção, A., Nascimento, A. R., \& Ximenes, P. A. (2009). Agronomic and nutritional caracters of genotypes of sweet corn. Bioscience Journal, 25, 104-112.

Ritchie, S. W., Hanway, J. J., \& Benson, G. O. (1993). How a corn plant develops. Ames: Iowa State University of Science and Technology.

Sangoi, L., Schmit, A., \& Zanin, C. G. (2007). Leaf area and grain yield of maize hybrids at different plant populations. Revista Brasileira de Milho e Sorgo, 6, 263-271. https://doi.org/10.18512/1980-6477/rbms. v6n3p263-271

Silva, M. A. V., Ferreira, W. P. M., Andrade, V. M. S., \& Araujo, S. G. A. (2010). Corn sowing time in Sete Lagoas region, Minas Gerais State, based on the probability of occurrence of dry and rainy spells. Revista Ceres, 57, 454-458. https://doi.org/10.1590/S0034-737X2010000400003

Soler, C. M. T., Sentelhas, P. C., \& Hoogenboom, G. (2005). Thermal time for phenological development of four maize hybrids grown off-season in a subtropical environment. Journal of Agricultural Science, 143, 169-182. https://doi.org/10.1017/S0021859605005198

Souza, R. S., Vidigal Filho, P. S., Scapim, C. A., Marques, O. J., Queiroz, D. C., Okumura, R. S., ... Cortinove, V. B. (2013). Yield and quality of sweet corn at different plant populations. Semina: Ciências Agrárias, 34, 995-1010.

Subedi, K. D., \& Ma, B. L. (2005). Ear position, leaf area, and contribution of individual leaves to grain yield in conventional and leafy maize hybrids. Crop Science, 45, 2246-2257. https://doi.org/10.2135/cropsci 2004.0653

Taiz, L., \& Zeiger, E. (2013). Fisiologia vegetal (p. 954). Porto Alegre: Artmed.

Tollenaar, M. (1989). Response of dry matter accumulation in maize to temperature. I. Dry matter partitioning. Crop Science, 29, 1239-1246. https://doi.org/10.2135/cropsci1989.0011183X002900050030x

Tsimba, R., Edmeades, G. O., Millner, J. P., \& Kemp, P. D. (2013a). The effect of planting date on maize grain yields and yield componentes. Field Crops Research, 150, 135-144. https://doi.org/10.1016/j.fcr.2013. 05.028

Tsimba, R., Edmeades, G. O., Millner, J. P., \& Kemp, P. D. (2013b). The effect of planting date on maize: Phenology, thermal time durations and growth rates in a cool temperate climate. Field Crops Research, 150, 145-155. https://doi.org/10.1016/j.fcr.2013.05.021

Waha, K., Müller, C., Bondeau, A., Dietrich, J. P., Kurukulasuriya, P., Heinke, J., \& Lotze-Campen, H. (2013). Adaptation to climate change through the choice of cropping system and sowing date in sub-Saharan Africa. Global Environmental Change, 23, 130-143. https://doi.org/10.1016/j.gloenvcha.2012.11.001

Wang, J., Wang, E., Yang, X., Zhang, F., \& Yin, H. (2012). Increased yield potential of wheat-maize cropping system in the North China Plain by climate change adaptation. Climatic Change, 113, 825-840. https://doi.org/10.1007/s10584-011-0385-1

Williams II, M. M. (2008). Sweet corn growth and yield responses to planting dates of the North Central United States. HortScience, 43, 1775-1779.

\section{Copyrights}

Copyright for this article is retained by the author(s), with first publication rights granted to the journal.

This is an open-access article distributed under the terms and conditions of the Creative Commons Attribution license (http://creativecommons.org/licenses/by/4.0/). 